
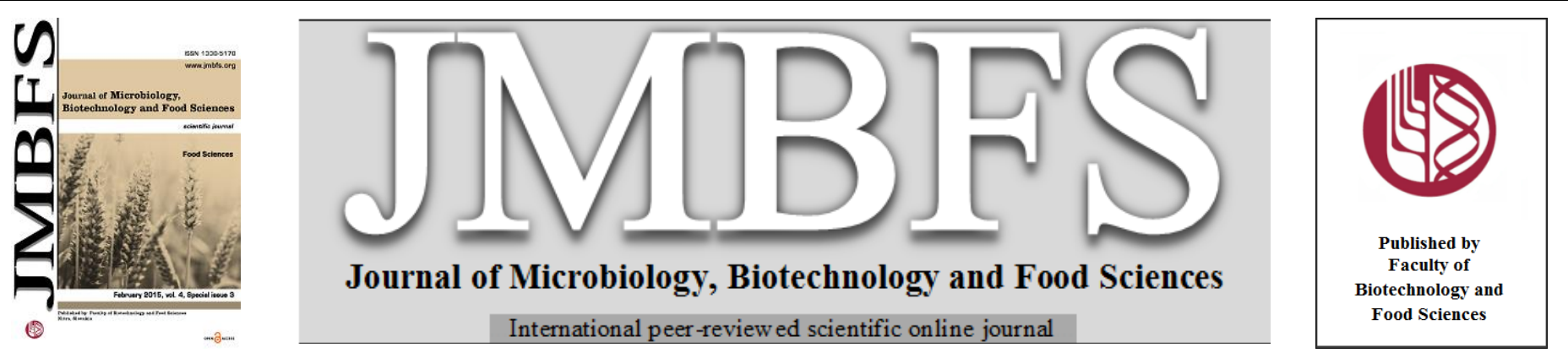

\title{
THE FREQUENCY OF DISTRIBUTION OF SOMATIC CELL COUNT IN DAIRY EWE'S MILK
}

\section{Sharaf Eldeen Idriss ${ }^{1}$, Vladimír Tančin ${ }^{* 1,2}$, Milan Margetín ${ }^{1,2}$, Dana Tančinová ${ }^{1}$, Petr Sláma ${ }^{3}$, Zdeněk Havliček $^{3}$}

Address(es): prof. Ing. Vladimír Tančin, DrSc.

${ }^{1}$ Slovak University of Agriculture in Nitra, Trieda A. Hlinku 2, 94976 Nitra, Slovak Republic:

${ }^{2}$ National Agricultural and Food Centre, RIAP Nitra, Hlohovecká 2, 95141 Lužianky, Slovak Republic, 00421903546401

${ }^{3}$ Mendel University Brno, Zemědelská 1, 61300 Brno, Czech Republic

*Corresponding author: tancin@vuzv.sk

doi: 10.15414/jmbfs.2015.4.special3.148-151

\section{ARTICLE INFO}

Received 27. 11.2014

Revised 3. 12. 2014

Accepted 4. 12. 2014

Published 2.2.2015

Regular article

open $\bigodot_{\text {access }}$

\section{ABSTRACT}

The objective of this study was to evaluate the situation in somatic cell counts in one selected herd throughout three-years period The was study performed in the experimental herd of the RIAP Nitra, Slovakia, bet ween 2010 and 2013. Genotypes of purebred T sigai (TS), Improved Valachian (IV) and Lacaune (LC) and their crossbred Tsigai $\times$ Lacaune $(T S \times L C)$ and Improved Valachian $\times$ Lacaune (IV $\times$ LC) ewes on their 1-3 lactation were investigated. SCC of milk was determined in 2632 milk samples collected from lactating dairy ewes. On the basis of SCC the dairy ewes were divided into the five groups: $\mathrm{G}_{1}=\mathrm{SCC}<100^{\times} 10^{3}$ cells. $\mathrm{ml}^{-1}, \mathrm{G}_{2}=\mathrm{SCC}$ bet ween 100 $300^{\times} 10^{3}$ cells. $\mathrm{ml}^{-1}, \mathrm{G}_{3}=\mathrm{SCC}$ bet ween $300-600^{\times} 10^{3}$ cells. $\mathrm{ml}^{-1}, \mathrm{G}_{4}=\mathrm{SCC}$ bet ween $600-1000^{\times} 10^{3}$ cells. $\mathrm{ml}^{-1}$ and $\mathrm{G}_{5}=\mathrm{SCC}>10^{6}$ cells. $\mathrm{ml}^{-1}$ to study the frequency of distribution of health problems of mammary gland in selected group of ewes throughout experimental period. In total the percentage of samples in first three groups was $78 \%$. The ewes of TS and IV had higher percentage of samples in G1 and lower in G5 as compared with L, TSxLC and IVxLC. In conclusion, the high percentage of ewes in a groups under $600 \times 10^{3}$ cells.ml ${ }^{-1}$ could indicate possible legislative limit for SCC related to good udder health in a future legislative.

Keywords: Dairy ewes, milk, somatic cell count

\section{INTRODUCTION}

Dairy sheep breeding in Slovakia is designed to last 15 years particular, on increasing milk production (Oravcová $\boldsymbol{e t ~ a l . , 2 0 0 5 ) , ~ b u t ~ i n c r e a s i n g l y ~ a l s o ~ f o c u s e s ~}$ on the functional properties that indirectly affect the economy of farming (Milerski et al., 2005).

The somatic cell count (SCC) is the basis for abnormal milk control programs for cows, goats and sheep (Bergonier-Berthelot, 2003). The SCC has evolved into an accepted parameter for the evaluation of milk quality and the price of raw milk within the dairy industry and as a management tool of udder health for dairymen worldwide. Ewes with a higher number of somatic cells have lower milk production and negatively affect other variables (lactose) and positive on fat and protein contents (Olechnowicz et al., 2009; Rupp et al., 2003). The SCC has evolved into an accepted parameter for the evaluation of milk quality and as a management tool of udder health for dairymen worldwide (Paape et al., 2007). Though SCC is mainly related to udder health but also varies because of a number of non-infective factors such as breed, stage of lactation, parity, type of lambing, type of milking, estrus, as well as diurnal, monthly and seasonal etc. (Kukovics et al., 2006; Raynal-Ljutovac et al., 2007).

In Slovakia, the milk from dairy ewes is used for making the cheese. Although the SCC is not considered as factor influencing the price of milk, it is also an important factor determining its yield and quality of the final product (Oravcová et al., 2007; Margetín et al., 2013). Individual SCC (SCC) is a useful predictor of infected gland, though there is no accepted threshold that can permit to different iate between "healthy" and "infected" udders in dairy ewes (Berthelot $\boldsymbol{t} t$ al., 2006). Last mentioned authors consider the udder as healthy if individual SCC is lower than $0.5^{\mathrm{x}} 10^{6}$ cells. $\mathrm{ml}^{-1}$, and infected if at least two individual SCC were higher than 1 or $1.2^{\mathrm{x}} 10^{6}$ cells. $\mathrm{ml}^{-1}$. In the European Union (EU) countries as in Slovakia, the legal limit for cows is $400^{\times} 10^{3}$ cells. $\mathrm{ml}^{-1}$ and there is no legal limit for goats and sheep.
The objective of this study was to evaluate the situation in somatic cell counts in one selected herd throughout three-years period with the possible relation to genetic and non-genetic factors.

\section{MATERIALS AND METHODS}

\section{Study area and experimental animals}

The study was performed in the experimental herd of the NPPC Research Institute for Animal Production Nitra, Slovakia, between 2010 and 2013. Genotypes of purebred T sigai (TS), Improved Valachian (IV) and Lacaune (LC) and their crossbred (Tsigai $\times$ Lacaune $(\mathrm{T} \mathrm{S} \times \mathrm{LC})$ and Improved Valachian $\times$ Lacaune $(\mathrm{IV} \times \mathrm{LC})$ ewes were investigated.

The ewes were milked twice daily at 7.00 and 19.00 hours. Machine milking was carried out in a 1 x 24 low-line, side by side milking parlour equipped with 12 milking units, by a single milking technician. Milking machine was set to provide 160 pulsations per minute ( $1: 1$ ratio with a vacuum level of $38 \mathrm{kPa}$ ). Milking was performed without any contact of hand with udder before cluster attachment (no stimulation, pre-dipping and fore-stripping). During each milking the ewes received in parlour $0.1 \mathrm{~kg}$ concentrate per head. Machine stripping with hand pressure to udder was done 10-20 s prior to removal of clusters.

Main period of lambing of ewes was detected during last week of January till the middle of March. Regular milk yield recording was performed during the morning milking in around the middle of April, May, June, July, and in some animals in August depending of the year. Individual milk samples were obtained from whole milk collection as an average sample. Milk samples were analyzed for somatic cells count. A total of 2632 milk samples from dairy ewes were individually collected. 


\section{Laboratory analysis}

Milk samples from each udder were transported to the certificated Central laboratory of Plemenárske služby š.p. Bratislava for milk analysis.

\section{Categories of somatic cell count (SCC)}

According to animals, the dairy ewes were divided into the five groups on the basis of individual SCC $\left(\mathrm{G}_{1}=\mathrm{SCC}<100^{\times} 10^{3}\right.$ cells. $\mathrm{ml}^{-1}, \mathrm{G}_{2}=\mathrm{SCC}$ between 100 -

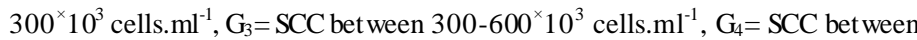
$600-1000^{\times} 10^{3}$ cells.ml ${ }^{-1}$ and $\mathrm{G}_{5}=\mathrm{SCC}>10^{6}$ cells. $\mathrm{ml}^{-1}$ to study the frequency of distribution of animals in selected group of ewes throughout experimental period The frequency of distribution of ewes in different SCC sorting groups was also study depending on year of study (three years), the parity (three parities - first, second and third), stage of lactation (calculated from the date of lambing till the date of milk recording to set up first month, second, third, fourth, fifth and sixth month), season (sampling periods - April, May, Jun, July, August) and breed and cross-breed. Statistical analysis was done by Microsoft Excel program.

\section{RESULTS AND DISCUSSION}

The detection of udder health in cattle, especially subclinical mastitis, is based on SCC. However in dairy sheep the physiological and pathophysiological thresholds of SCC are still no established (Berthelot et al., 2006). Our results showed that from total of 2632 examined milk samples, the most milk samples were classified within $\mathrm{G}_{1} \mathrm{SCC}$ group $\left(<100 \times 10^{3}\right.$ cells. $\left.\mathrm{ml}^{-1}\right)$ with $40.69 \%$. The year of study positively influenced the frequency of distribution of animals in groups. The udder health status of ewes had clearly improved during the following years and caused the rise of percentages of samples in SCC less than

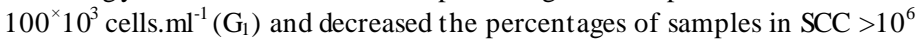
cells. $\mathrm{ml}^{-1}\left(\mathrm{G}_{5}\right)$ in milk at the end of the survey. In total the percentage of samples in first three groups was $78 \%$, even in 2013 the value was $83 \%$. Improving the SCC stat us in ewes from year to year of study and high \% of animals under $10^{6}$ cells $/ \mathrm{ml}$ correspond to results of another authors (Berthelot et al., 2006) which could be explained by the high percentage of bacteriologically negative milk samples in another study from Slovakia (Vasil et al., 2013). The presences of microorganisms also influence the SCC if the udder is infected by "minor" or "major" pathogens (Suarez et al., 2002). Last mentioned author found out those negative samples (free of microorganisms) had arithmetic means 244470 cells. $\mathrm{ml}^{-1}$, samples contaminated with minor pathogens reached means 1044100 cells. $\mathrm{ml}^{-1}$ and samples with major pathogens 2045652 cells. $\mathrm{ml}^{-1}$. Thus the study of relationship between infection (presence of pathogens in udder) and SCC in milk is required under condition of sheep dairy farming in Slovakia more in detail. The changes in milk samples distribution throughout evaluated years indicate great possibilities to improve udder health in the dairy practice.

Table 1 Frequency of distribution of SCC in milk samples from ewes during 2010-2013

\begin{tabular}{|c|c|c|c|c|c|c|}
\hline \multirow{2}{*}{ Years } & \multirow{2}{*}{$\mathbf{N}$} & \multicolumn{5}{|c|}{$\operatorname{SCC}\left(10^{3}\right.$ cells.ml $\left.{ }^{-1}\right)$ in $\%$} \\
\hline & & G1 & $\mathbf{G}_{2}$ & G3 & $\mathbf{G}_{4}$ & G5 \\
\hline 2010 & 648 & 30.56 & 27.31 & 13.73 & 7.41 & 20.99 \\
\hline 2011 & 726 & 33.61 & 30.3 & 12.81 & 8.40 & 15.15 \\
\hline 2012 & 615 & 44.39 & 28.13 & 8.62 & 5.37 & 13.50 \\
\hline 2013 & 643 & 55.37 & 19.91 & 7.78 & 4.51 & 12.44 \\
\hline Total & 2632 & 40.69 & 26.44 & 10.83 & 6.50 & 15.50 \\
\hline
\end{tabular}

According to the individual breeds and their crossbreds in $G_{1}$, the lowest percentage was calculated in crossbreds Improved Valachian cross Lacaune (IV×LC) with $38.63 \%$, followed Lacaune (LC) with $38.82 \%$, crossbred of T sigai and Lacaune (TS $\times$ LC) with $41.03 \%$ and the highest in T sigai (TS) with $47.39 \%$ (Table 2). Whilst, in Improved Valachian (IV) it is very difficult to interpret the results of this breed, because the number of ewes was low (only 54 milk samples). Margetín et al. (2013) did not find out significant differences among above mentioned genotype groups. Higher SCC was found out in L as compared with Manchega ewes (Rovai et al., 2014).

Table 2 Frequency of distribution of SCC in milk samples from different breeds and their crossbreds

\begin{tabular}{|c|c|c|c|c|c|c|}
\hline \multirow{2}{*}{ Breeds } & \multirow{2}{*}{$\mathbf{N}$} & \multicolumn{5}{|c|}{$\operatorname{SCC}\left(10^{3}\right.$ cells.ml $\left.{ }^{-1}\right)$ in $\%$} \\
\hline & & $\mathbf{G}_{1}$ & $\mathbf{G}_{2}$ & G3 & $\mathbf{G}_{4}$ & G5 \\
\hline TS & 211 & 47.39 & 29.38 & 9.00 & 5.21 & 9.00 \\
\hline $\mathrm{TS} \times \mathrm{LC}$ & 814 & 41.03 & 23.10 & 12.41 & 6.63 & 16.83 \\
\hline $\mathrm{LC}$ & 577 & 38.82 & 27.4 & 11.61 & 6.7 & 16.46 \\
\hline IV & 54 & 66.67 & 24.7 & 5.56 & 3.70 & 0.00 \\
\hline $\mathrm{IV} \times \mathrm{LC}$ & 976 & 38.63 & 28.38 & 9.73 & 7.7 & 16.19 \\
\hline
\end{tabular}

SCC- Somatic cell count, TS- T sigai, LC- Lacaune, IV- Improved Valachian, T S $\times$ LC- crossbreeds,

IV $\times$ LC- crossbreeds

For groups see table 1 .

The frequency of distribution of SCC in milk samples in different numbers of lact ation (parity) of dairy ewes were recorded in Table 3. The highest percentages of ewes in G1 group were in first lactating ewes, followed by second and third lact ating ones. With the exception of 1 -year-old ewes, no significant differences were observed in SCC as affected by age or parity (Suarez et al., 2002). Similar results were published by Arias et al. (2012), who did not see the effect of parity on SCC except first lactation. Paape et al. (2007) did not find out changes in SCC with increasing of parity.
The results of frequency of distribution of SCC in milk samples from ewes in (stage) months of lactation are presented in Table 4 . Animals in the first month of lactation showed the highest percentage of samples in the groups below $600 \times 10^{3}$ cells. $\mathrm{ml}^{-1}$. In the second month the number of ewes in $\mathrm{G}_{5}$ increased clearly. Higher frequency of milk samples in $\mathrm{G}_{5}$ in second months of lactation which also corresponding to season (April, table 5) could reflect possible stress effect from weaning and swift to machine milking as we also recently presented (Antonič $\boldsymbol{e t}$ al., 2013). Romeo et al. (1996) found out that SCC in milk from uninfected 
udder ewes increased afterfifth months which correspond to our results (Table 4). SCC changes throughout lactation are connected to the parity in dairy ewes (Paape et al., 2007). Las mentioned authors found out similar changes throughout lactation as we are presenting but not in all parities. In general, mentioned authors pointed out that non-infectious factors such as parity and stage of lactation had minimal effects on SCC for sheep.

Table 3 Frequency of distribution of SCC in milk samples in different numbers of lactation (parity)

\begin{tabular}{|c|c|c|c|c|c|c|}
\hline \multirow{2}{*}{ Lactations } & \multirow{2}{*}{$\mathbf{N}$} & \multicolumn{5}{|c|}{$\operatorname{SCC}\left(10^{3}\right.$ cells.ml $\left.{ }^{-1}\right)$ in $\%$} \\
\hline & & $\mathbf{G}_{1}$ & $\mathbf{G}_{2}$ & $\mathbf{G}_{3}$ & $\mathbf{G}_{4}$ & G5 \\
\hline First & 1040 & 47.02 & 26.83 & 9.42 & 4.90 & 11.83 \\
\hline Second & 869 & 45.44 & 23.53 & 11.53 & 7.728 & 11.76 \\
\hline Third & 725 & 25.93 & 29.38 & 12 & 7.31 & 25.38 \\
\hline
\end{tabular}

For groups see table 1 .

Table 4 Frequency of distribution of SCC in milk samples in different stage of lactation

\begin{tabular}{|c|c|c|c|c|c|c|}
\hline \multirow{2}{*}{$\begin{array}{l}\text { Month in } \\
\text { milk }\end{array}$} & \multirow{2}{*}{$\mathbf{N}$} & \multicolumn{5}{|c|}{$\operatorname{SCC}\left(10^{3}\right.$ cells.ml $\left.l^{-1}\right)$ in $\%$} \\
\hline & & $\mathbf{G}_{1}$ & $\mathbf{G}_{2}$ & G3 & $\mathbf{G}_{4}$ & G5 \\
\hline First & 47 & 44.68 & 36.17 & 8.51 & 4.26 & 6.38 \\
\hline Second & 603 & 35.16 & 28.19 & 11.61 & 5.31 & 19.73 \\
\hline Third & 547 & 43.30 & 25.87 & 8.62 & 6.6 & 16.15 \\
\hline Fourth & 662 & 41.84 & 23.56 & 11.93 & 7.55 & 15.12 \\
\hline Fifth & 648 & 42.90 & 27.16 & 10.80 & 7.10 & 12.4 \\
\hline Sixth & 127 & 36.22 & 29.13 & 11.81 & 6.30 & 16.54 \\
\hline
\end{tabular}

Table 5 shows the frequency of distribution of SCC in milk samples in different months (season) of the year. Higher frequency of SCC in $\mathrm{G}_{1}$ was shown during the period of June, July and August (summer month), compared with April and May (spring months). Arias et al. (2012) found out significant lower SCC during spring than during summer and winter period which does not corresponds to our findings. Our experimental animals were lambing in winter period and thus the seasonal changes in the frequency of SCC distribution are related to the stage of lactation (Table 4) though housing of ewes in April was inside the sheepfold, which is warm and, humid, supplying increased susceptibility to environmental pathogens (Marogna et al., 2010).

Table 5 Frequency of distribution of SCC in milk samples in different season (months)

\begin{tabular}{|c|c|c|c|c|c|c|}
\hline \multirow{2}{*}{$\begin{array}{c}\text { Season/ } \\
\text { (months) }\end{array}$} & \multirow{2}{*}{$\mathbf{N}$} & \multicolumn{5}{|c|}{$\operatorname{SCC}\left(10^{3}\right.$ cells.ml $\left.l^{-1}\right)$ in $\%$} \\
\hline & & $\mathbf{G}_{1}$ & $\mathbf{G}_{2}$ & $\mathbf{G}_{3}$ & $\mathbf{G}_{4}$ & G5 \\
\hline April & 603 & 34.16 & 29.19 & 11.61 & 5.14 & 19.90 \\
\hline May & 499 & 40.68 & 27.5 & 9.22 & 7.21 & 15.83 \\
\hline June & 708 & 43.79 & 21.89 & 12.1 & 6.78 & 15.54 \\
\hline July & 716 & 42.04 & 29.33 & 10.6 & 7.12 & 11.45 \\
\hline August & 103 & 47.57 & 18.45 & 11.65 & 4.85 & 17.48 \\
\hline
\end{tabular}

For groups see table 1 .

\section{CONCLUSION}

In our study in total the percentage of samples in first three groups below $600^{\times} 10^{3}$ cells. $\mathrm{ml}^{-1}$ was $78 \%$, which indicate possible good health stat us of experimental ewes. The ewes of TS and IV had higher percentage of samples in G1 and lower in G5 as compared with L, T SxLC and IVxLC. Obtained results could indicate possible legislative limit for SCC related to good udder health in a future legislative. However more detail study is needed to see relationship between high SCC and presence of microorganisms to better understanding the reasons the physiological and pathological SCC in the udder.

Acknowledgements: This publication was written during realization of the project "MLIEKO No 26220220196" supported by the Operational Programme Research and Development funded from the European Regional Development Fund. Kega 006SPU-4/2014 "Modernization of teaching of domestic animal hygiene".

\section{REFERENCES}

ANT ONIČ, J., JACKULIAKOVÁ, L., UHRINČǍ̌, M., MAČUHOVÁ, L., ORAVCOVÁ, M., T ANČIN, V. 2013. Changes in milk yield and composition after lamb weaning and start of machine milking in dairy ewes. Slovak Journal of Animal Science, 46(3), 93-99.

ARIAS, R., OLIETE, B., RAM, M., ARIAS, C., GALLEGO, R., MONTORO, V., GONZALO, C. AND EZ-GUZM, M. D. P. 2012. Long-term study of environmental effects on test-day somatic cell count and milk yield in Manchega sheep. Small Ruminant Research, 106(2-3), 92-97. http://dx.doi.org/10.1016/j.smallrumres.2012.03.019

BERGONIER, D., BERT HELOT, X. 2003: New advances in epizootiology and control of ewe mastitis. Livestock Production of Science, 79(1), 1-16. $\mathrm{http}: / / \mathrm{dx}$.doi.org/10.1016/s0301-6226(02)00145-8

BERTHELOT X., LAGRIFFOUL, G., CONCORDET, D., BARILETT, F., BERGONIER. D. 2006. Physiological and pathological thresholds of somatic cell counts in ewe milk. Small Ruminant Research, 62(1-2), 27-31. http://dx.doi.org/10.1016/j.smallrum res.2005.07.047

KUKOVICS, S., MOLNAR, A., ABRAHAM, M., NEMETH,T., KOMLOSI, I. 2006. Effects of udder traits on the milk yield of sheep. Archiv fur Tierzucht, 49(2), 165-175

MARGETÍN, M., MILERSKI, M., APOLEN, D., ČAPISTRÁK, A., ORAVCOVÁ, M., DEBRECÉNI, O. 2013: Relationships between production, 
quality of milk and udder health st atus of ewes during machine milking. Journal of Central European Agriculture, 14(1), 328-340. http://dx.doi.org/10.5513/jcea01/14.1.1203

MAROGNA, G., ROLESU, S., LOLLAI, S., TOLA, S., LEORI, G. 2010. Clinical findings in sheep farms affected by recurrent bacterial mastitis. Small Ruminant Research, $88(2-3)$,

119-125. http://dx.doi.org/10.1016/j.smallrumres.2009.12.019

MILERSKI, M., MARGETÍN, M., APOLEN, D., ČAPISTRÁK, A., ŠPÁNIK, J. 2005. Udder cistern size and milkability of ewes of various genotypes, in Conference on „Physiological and technical aspects of machine milking, Nitra, 2005, ICAR Technical series No. 10, pp. 63-69 (ISSN 1563-2504, ISBN $92-$ 95014-07-3).

OLECHNOWICZ, J., JAŚKOWSKI, J. M., ANT OSIK, P., BUKOWSKA, D. 2009. Milk yield and composition in line 05 dairy ewes as related to somatic cell counts. Journal of Animal and Feed Sciences, 18, 420-428.

ORAVCOVÁ, M., GROENEVELD, E., KOVAČ, M., PEŠKOVIČOVÁ, D., MARGETIN, M. 2005. Estimation of genetic and environmental parameters of milk production traits in Slovak purebred sheep using test-day model. Small Ruminant Research, 56(1-3), 113-120. http://dx.doi.org/10.1016/j.smallrumres.2004.03.002

ORAVCOVÁ M., M. MARGET, D. PEŠKOVIČOVÁ, J. DAŇO, M. MILERSKI, L. HETÉNYI,P. POLÁK 2007: Factors affecting ewe's milk fat and protein content and relationships between milk yield and milk components. Czech Journal of Animal Science, 52(7), 189-198.

PAAPE, M. J., WIGGANS, G. R., BANNERMAN, D. D., THOMAS, D. L. SANDERS, A. H., CONTRERAS, A., MORONI, P., MILLER, R. H. 2007. Monitoring goat and sheep milk somatic cell counts. Small Ruminant Research, 68(1-2), 114-125. http://dx.doi.org/10.1016/j.smallrumres.2006.09.014
RAYNAL-LJUT OVAC, K., PIRISI, A., DE CRÉMOUX, R., GONZALO, C. 2007: Somatic cells of goats and sheep milk: Analytical, sanitary, productive and technological aspects. Small Ruminant Research, 68(1-2), 126-44. http://dx.doi.org/10.1016/j.smallrumres.2006.09.012

ROMEO, M., EST NAL, A., CONTRERAS, A., ADURIZ, J.J., GONZALEZ, L., MARCO, J.C. 1996. Evolution of milk somatic cell counts along the lactation period in sheep of the Laxtra breed. Somatic cell and milk of Small Ruminants. In. Proceedings of the International Symposium, vol. 77, Bella, Italy. EAAP Publication, pp. 21-25.

ROVAI, M., CAJA, G., SALAMA, A. A. K., JUBERT, A., LÁZARO, B., LÁZARO, M., LEITNER, G. 2014. Identifying the major bacteria causing intramammary infections in individual milk samples of sheep and goats using traditional bacteriacult uring and real-time polymerase chain reaction. Journal of Dairy Science, 97 :5393-5400. http://dx.doi.org/10.3168/jds.2014-7988 RUPP, R., LAGRIFFOUL, G., AST RUC, J. M., BARILETT F. 2003. Genetic Parameters for Milk Somatic Cell Scores and Relationships with Production Traits in French Lacaune Dairy Sheep. Journal of Dairy Science, 86(4), 14761481. http://dx.doi.org/10.3168/jds.s0022-0302(03)73732-1

SUAREZ, V.H, BUSET TI, M.R., MIRANDA, A.O., CALVINHO, L.F., BEDOT TI,D.O., CANAVESIO, V.R. 2002. Effect of infectious status and parity on somatic cell count and California mastitis test in pampinta dairy ewes. Joumal of veterinary medicine series $b$-infectious diseases and veterinary publichealth, 49(5), 230-234. http://dx.doi.org/10.1046/j.1439-0450.2002.00552.x

VASIL, M., ELEČKO, J., FARKAŠOVÁ, Z., ZIGO, F. 2013. [Aetiology of environmental mastitis in sheep and the occurrence of antibiotic resistance in bacteria isolated from clinical forms]. Potravinárstvo, 7, Special Issue, 20-24. http://dx.doi.org/10.5219/171 